\title{
Detecting conflicts of interest in credit rating changes: a distribution dynamics approach
}

\author{
Wai Choi Lee ${ }^{1}$, Jianfu Shen ${ }^{2 *}$, ${ }^{*}$ Tsun Se Cheong ${ }^{1}$ and Michal Wojewodzki ${ }^{1}$
}

\section{*Correspondence:}

jeff.jf.shen@polyu.edu.hk

2 ZN721, Block Z, Department

of Building and Real Estate,

The Hong Kong Polytechnic

University, Hung Hom, Hong

Kong, China

Full list of author information

is available at the end of the

article

\begin{abstract}
In this study, we compare the adjustments of credit ratings by an investor-paid credit rating agency (CRA), represented by Egan-Jones Ratings Company, and an issuer-paid CRA, represented by Moody's Investors Service, vis-à-vis conflict of interest and reputation. A novel distribution dynamics approach is employed to compute the probability distribution and, hence, the downgrade and upgrade probabilities of a credit rating assigned by these two CRAs of different compensation systems based on the dataset of 750 U.S. issuers between 2011 and 2018, that is, after the passage of the Dodd-Frank Act. It is found that investor-paid ratings are more likely to be downgraded than issuerpaid ratings only in the lower rating grades, which is consistent with the argument that investor-paid agencies have harsher attitudes toward potentially defaulting issuers to protect their reputation. We do not find evidence that issuer-paid CRAs provide overly favorable treatments to issuers with threshold ratings, implying that reputation concerns and the Dodd-Frank regulation mitigate the conflict of interests, while issuerpaid CRAs are more concerned about providing accurate ratings.
\end{abstract}

Keywords: Credit ratings, Conflict of interest, Distribution dynamics, Issuer-paid credit rating agencies, Investor-paid credit rating agencies

\section{Introduction}

The accuracy and timeliness of issuer-paid credit ratings have generated several discussions in the last two decades after the sudden collapses of Enron, WorldCom, and Lehman Brothers, which enjoyed investment grade ratings shortly before their respective downfalls. The issuer-paid rating model has been adopted by most credit rating agencies (CRAs), including the Big Three, that is, Standard \& Poor's Global Ratings (S\&P), Moody's Investors Service (Moody's), and Fitch Ratings. Such a model, wherein CRAs generate revenues from the issuers they rate, has been severely criticized for the conflict of interest between issuer-paid CRAs and issuers. More specifically, issuer-paid rating agencies have been accused of deliberately assigning overly favorable ratings to issuers and being too slow to downgrade the ratings in response to the deterioration of the issuers' credit quality (Baghai and Becker 2018; Efing and Hau 2015; He et al. 2012; Kedia et al. 2017; Kraft 2015; Parnes 2018; White 2019). However, issuer-paid CRAs argue that as they focus more on maintaining their reputation capital, which is crucial for long-run success in the industry, they provide unbiased credit ratings (Covitz and Harrison 2003; author(s) and the source, provide a link to the Creative Commons licence, and indicate if changes were made. The images or other third party material in this article are included in the article's Creative Commons licence, unless indicated otherwise in a credit line to the material. If material is not included in the article's Creative Commons licence and your intended use is not permitted by statutory regulation or exceeds the permitted use, you will need to obtain permission directly from the copyright holder. To view a copy of this licence, visit http:// creativecommons.org/licenses/by/4.0/. 
De Haan 2017; Dimitrov et al. 2015; Pittman 2008; SEC 2003). Issuer-paid CRAs further argue that owing to the access to issuers' private information, they can assess the credit quality of the issuers accurately.

An alternative to the issuer-paid model is the investor-paid model wherein an institutional investor pays for the rating advice from a rating agency. Egan-Jones Ratings Company (EJR), a representative investor-paid CRA, claims that the investor-paid model is free of conflict of interest (see SEC 2020b). ${ }^{1}$ Empirical studies conducted by Cornaggia and Cornaggia (2013), Jiang et al. (2012), and Xia and Strobl (2012) show that the investor-paid model is superior to the issuer-paid one in terms of rating accuracy and timeliness. However, the investor-paid model is notorious for its conflict of interest with investors (Tang et al. 2020) and information disadvantage owing to the lack of private information provided by the issuers (Bonsall 2014; Bonsall et al. 2017). Furthermore, to avoid reputational loss in the missed defaults, investor-paid agencies may strategically assign a lower rating to a firm if the issuer's default probability is significant. In other words, investor-paid rating agencies have an alternative type of conflict of interest (with investors or themselves), which may lead to negatively biased (deflated) ratings. In the present study, we adopt a distribution dynamics approach (DDA) introduced by Quah (1993) to compare the likelihood of rating changes of the issuers assigned by these two CRAs of different business models and explore how the conflicts of interest affect issuerand investor-paid rating changes.

Using a sample of 750 U.S. issuers with ratings from EJR and Moody's between 2011 and 2018, we find that EJR is more likely to downgrade issuers with rating grades below B- than Moody's. The results support our hypothesis that owing to a lack of private information and the reputational concern of avoiding missed defaults, an investor-paid CRA strategically treats potentially defaulting issuers more harshly than an issuer-paid CRA, even though the issuers do not default subsequently. An alternative explanation is that the issuer-paid CRA is reluctant to downgrade the issuers owing to the issuer-paid business model. However, we do not find evidence that the downgrade probabilities of EJR's ratings are consistently higher than those of Moody's in the rating grades of B-and above. Such results imply that the cost of missed defaults and the loss of reputational capital are dominant considerations of the investor-paid CRA which assigns ratings to potentially defaulting issuers.

Furthermore, we explicitly test whether issuer-paid ratings are more likely to be affected by the conflict of interest than investor-paid ratings by comparing the probabilities of rating changes in threshold rating grades. ${ }^{2}$ Because rating changes across broad categories, especially from investment to speculative grade, are associated with significant increases in access to capital and its costs to an issuer (Kisgen 2006), the conflict of interest with issuers might cause Moody's to less likely downgrade issuers with downside

\footnotetext{
${ }^{1}$ EJR is an independent rating agency founded in 1995. It covers several companies across all industries rated by major issuer-paid agencies. In December 2007, EJR became the first investor-paid agency to be granted the title of nationally recognized statistical ratings organization (NRSRO) by the U.S. Securities and Exchange Commission (SEC). The NRSRO title certifies EJR as a "nationally recognized" rating agency that provides "credible and reliable" issuer ratings.

2 The threshold rating grades are those close to adjacent rating categories. EJR (Moody's) denotes the downside and upside threshold rating by adding a minus sign (number 3) and a plus sign (number 1) as a suffix to their major rating category, respectively. For example, EJR's BBB- (Moody's Baa3) downside threshold rating is close to a downgrade to a lower BB (Ba) rating category, while EJR's BBB+ (Moody's Baa1) upside threshold rating is close to an upgrade to a higher A rating category.
} 
threshold rating grades than EJR. By the same token, Moody's is more likely to upgrade issuers with upside threshold rating grades than EJR. However, our findings do not support this argument. The probabilities of rating changes in the threshold rating grades are not consistently and substantially different for both rating agencies. Such evidence suggests that the issuer-paid CRA's concern about its long-run reputation neutralizes the potential temptation to please an issuer through overly favorable ratings (Covitz and Harrison 2003; SEC 2003). Moreover, with the expanded power to govern CRAs, ${ }^{3}$ the U.S. Securities and Exchange Commission (SEC) and the Office of Credit Ratings (OCR) might also mitigate the issuer-paid CRA's conflict of interest with the issuer. Thus, the adjustment differences between investor- and issuer-paid ratings are reduced.

The present study makes the following contributions to the existing empirical literature and regulators by providing a new perspective on the comparison of rating changes by nationally recognized statistical rating organizations (NRSROs) with different business models. To the best of our knowledge, we are the first to use the DDA which provides a comprehensive view of the rating changes and can be used to compare the rating performances from different agencies and business models in the full spectrum of the rating grades. The approach is a novel and important supplement to the current methodologies in credit rating studies that assess rating performances based on the occurrences of extreme credit events, that is, bankruptcies or defaults (Cornaggia, and Cornaggia 2013; Bonsall 2014; Beaver et al. 2006; Xia 2014).

Furthermore, unlike the previous studies that only explore the conflict of interest in issuer-paid rating agencies (Baghai and Becker 2018; Efing and Hau 2015; Kedia et al. 2017), the present study tests the conflict of interest arguments in both business models. Our findings do not provide consistent and solid support to the argument that issuer-paid agencies assign favorable ratings and delay the downgrades to please issuers; however, they raise concerns about the bias of investor-paid ratings owing to the investor-paid CRAs' self-interest to maintain their reputation. Thus, the empirical evidence of our study suggests that the investor-paid business model may not be a valid alternative solution to the ongoing problems in the credit rating industry.

Our study also yields some policy implications to regulators. In a response to the 2008 financial crisis, the U.S. Congress passed the Dodd-Frank Wall Street Reform and Consumer Protection Act of 2010 (the Dodd-Frank Act). Regarding CRAs, the Dodd-Frank Act has brought about the biggest change since 1934 by mandating the SEC with extensive regulatory powers over NRSROs. ${ }^{4}$ The OCR is responsible for examining NRSROs' annual reports which include transition matrices of annual rating changes (White 2019). Our research method may aid the OCR in its annual examination of the NRSROs by delivering insights in addition to those from the transition matrices of annual rating changes submitted by the NRSROs. More specifically, the DDA can assist the OCR

\footnotetext{
${ }^{3}$ Since its inception, the OCR has used its prerogative to impose fines on non-compliant CRAs and prohibit them from issuing specific ratings for as long as necessary. For example, in January 2013, EJR was barred from rating governmentissued (sovereigns, US states, and local) and asset-backed securities (Scannell 2013), while in January 2015, S\&P was fined \$58million and barred from rating commercial mortgage-backed securities for 1 year (SEC 2015).

4 The Office of Credit Ratings (OCR) has been created to assist the SEC in executing its mandated powers (SEC 2021). For instance, the OCR is responsible for the scrutiny of the NRSROs and alternative compensation models for potentia conflicts of interest, promotes NRSROs transparency and disclosure, and enhances the accuracy/performance of ratings issued (SEC 2021).
} 
in assessing (forecasting) the historical (future) performance of ratings issued by each $\mathrm{NRSRO}^{5}$ and evaluating alternative rating business models from a conflict-of-interest perspective (White 2019; SEC 2021).

The rest of the paper is structured as follows: the previous literature is reviewed and the hypotheses are specified in second section, while the DDA and the data are described in third section. The results are presented and discussed in fourth section, while the conclusions are given in the last section.

\section{Literature review and hypothesis development}

Credit rating agencies play a central role in capital markets as they assess the creditworthiness of issuers and securities issued by them, provide this information to market participants, and control the potential default risk (e.g., Kisgen 2006; Wang et al. 2020). Major CRAs, i.e., S\&P, Moody's, and Fitch, adopt the issuer-paid business model; that is, they rely upon revenues from rated issuers. With a sizeable team of analysts, major issuer-paid agencies are probably capable of producing accurate and timely credit information (Bonsall et al. 2017). However, the conflict of interest between issuer-paid CRAs and issuers is alleged to occur because of the issuer-paid compensation system model. To secure revenues from issuers, issuer-paid CRAs assign inflated ratings that are unaligned with the issuers' credit quality and financial securities issued by them. Well-cited examples include the slow response of issuer-paid CRAs to the bankruptcy of Lehman Brothers and favorable credit ratings to structured finance products (White 2019) or corporate bonds (Parnes 2018). Many studies have documented that issuer-paid CRAs assign favorable (inflated) ratings to the issuers they maintain strong business relationships with (Efing and Hau 2015), they collect revenues of non-rating service from the issuers (Baghai and Becker 2018), the issuers are large (He et al. 2012), the investees are the large shareholders of Moody's or S\&P (Kedia et al. 2017), or there are rating-based performance pricing provisions stipulated in loan contracts (Kraft 2015).

Notwithstanding the above-outlined evidence, issuer-paid CRAs argue that longterm reputation is more important to them than short-term revenues (Pittman 2008), and thus, the conflict of interest is effectively managed (Covitz and Harrison 2003; SEC 2003). If an issuer-paid CRA's favoritism to one or more issuers is detected by the financial markets, the market participants will cease (or at least reduce) to trust in the accuracy of that CRA's future ratings. This consequently implies that the markets will decrease the use of the CRA's ratings (De Haan 2017), and future issuers will refrain from hiring such CRA (e.g., Bolton et al. 2012). Accordingly, as the expected long-run gains from maintaining a reputation for accuracy exceed the short-run gains of favoritism to one or more issuers, the issuer-paid CRA strives to provide accurate ratings and avoid the temptation of pleasing the issuers. For example, Berwart et al. (2019) report that greater investor scrutiny increases political pressure and recent regulatory reforms imposed on the U.S. rating industry. Berwart et al. (2019) further argue that these factors "are likely to have modified the relative incentives of CRAs, affecting the likelihood

${ }^{5}$ Parnes and Akron (2016) develop 'a benchmark array of flawless ratings' and argue that it can assist the OCR in assessing the historical performance of ratings issued by NRSROs. However, their study is based on the issuer-paid CRAs. 
of reputational losses exceeding the costs of currying favor with bond issuers; thus, we expect issuer-paid CRAs to have improved their rating timeliness" (p. 89).

Some studies show that the potential conflict of interest in the issuer-paid business model has been mitigated since the passage of the Dodd-Frank Act. Dimitrov et al. (2015) find that issuer-paid CRAs have become more conservative following the DoddFrank Act due to their reputational concerns. De Haan (2017) documents an improvement in the performance of ratings produced by the Big Three issuer-paid CRAs as a response to increased regulatory scrutiny and reputational pressure from the markets. Toscano (2020) finds that issuer-paid CRAs focus more on timely rating adjustments than investor-paid CRAs after the passage of the Dodd-Frank Act, while rating accuracy has also improved.

An alternative model in the rating industry is the investor-paid model, wherein CRAs charge fees from the subscribers who are typically institutional investors (Bonsall et al. 2017). In the past, S\&P and Moody's had adopted the investor-paid business model but they switched to the issuer-paid model in the 1970s largely due to the free-rider problem caused by information sharing technology (White 2019). Currently, among the nine CRAs certified as a "nationally recognized" rating agency by the U.S. SEC, only the EJR operates solely under the investor-paid model, whereas other CRAs adopt the issuerpaid model ${ }^{6}$ (SEC 2020a).

The EJR claims that the investor-paid model is free from potential conflict and thus provides timely and unbiased credit ratings to the market which are superior to those offered by issuer-paid CRAs. ${ }^{7}$ For instance, EJR downgraded ratings timelier than large issuer-paid rating agencies before the bankruptcies of Enron, WorldCom, Bear Stearns, Lehman Brothers, and others. Some studies, for example, Jiang et al. (2012), Xia and Strobl (2012), and Cornaggia and Cornaggia (2013), have concluded that the investorpaid model has been superior to the issuer-paid model in terms of the accuracy and timeliness of credit ratings before the passage of the Dodd-Frank Act. Bhattacharya et al. (2019) find that between 1999 and 2010, small institutional investors who consistently follow ratings issued by EJR in their trading decisions tend to outperform the nonfollowing investors and benefit from improved performance after becoming followers. The parsimonious optimal contracting model developed by Kashyap and Kovrijnykh (2016) also indicates that the investor-paid model should be more accurate than the issuer-paid model.

However, SEC (2012) and issuer-paid agencies, including S\&P, Moody's, and Fitch, argue that the investor-paid model also has an inherent conflict of interest issue as investor-paid CRAs have an incentive to please investors rather than issuers. Some scholars also support such assertions (Calomiris 2009). For example, Tang et al. (2020) argue that if investor-paid agencies know their clients' investment positions, they may provide biased ratings in favor of investors, which creates a conflict of interest between investorpaid agents and investors. Moreover, compared with issuer-paid agencies, investor-paid agencies are confronted with an information disadvantage problem because they do not

\footnotetext{
${ }^{6}$ Kroll Bond Rating Agency adopts a blended approach by offering both investor- and issuer-paid credit ratings.

7 In an open letter to the SEC from 20th of January 2020, Sean Egan (the founder and CEO of EJR) claimed that the investor-paid rating model adopted by EJR was a "ready solution" to the conflict-of-interest problem inherent in the issuer-paid rating model, unsolved despite the Dodd-Frank Act (SEC 2020b).
} 
have access to the management of the issuers but only rely on publicly available information, such as financial statements, ${ }^{8}$ and have merely a few analysts available during the rating process ${ }^{9}$ (Bonsall 2014; Bonsall et al. 2017).

\section{Hypotheses development}

Given the reputational concerns and information disadvantage, investor-paid agencies may strategically assign a lower rating to an issuer. Based on the regulatory reforms in the U.S. during the last two decades, ${ }^{10}$ the legal penalties (or reputational loss) are not symmetric with regards to downward biased (overly pessimistic) and upward biased (overly optimistic) ratings (Dimitrov et al. 2015). Notably, EJR is an investor-paid NRSRO with a strong reputation largely built on its historical record (unlike the major three issuer-paid CRAs) of the early detection of defaulting firms (e.g., Enron, WorldCom, Bear Stearns, and Lehman Brothers). Thus, EJR might be incentivized to protect its esteemed reputation capital by underrating issuers with a relatively high default probability (poor rating grades), for example, in the rating category below B, similar to the situation of unsolicited ratings (Fulghieri et al. 2014). ${ }^{11}$ However, the underrating may be unobservable in issuers far from potentially defaulting, that is, with better ratings. Furthermore, the downward rating bias may be amplified when investor-paid CRAs have more significant information disadvantages about issuers in lower rating grades (Bonsall 2014; Bonsall et al. 2017; Atilgan et al. 2015). We present the first hypothesis about the harsher investor-paid ratings to potentially defaulting issuers as follows:

H1 (self-interest in investor-paid CRAs): Investor-paid ratings are more likely to be downgraded than issuer-paid ratings only in the lower rating grades.

Next, we explore when (and whether) issuer-paid agencies may sacrifice their reputation and provide favorable treatments to issuers. Overly favorable ratings may be assigned when they can strongly benefit the issuers. A possible situation is when an issuer rated by an issuer-paid agency has a threshold rating; as Kisgen (2006) argues, the capital costs are significantly different in the rating levels across the broad rating categories. Therefore, if the conflict of interest in the issuer-paid business model matters, an issuer with Moody's (issuer-paid CRA) downside threshold rating (e.g., Aa3) is less likely to be downgraded to a lower broad rating category (e.g., A2) than an issuer with EJR's corresponding downside threshold rating (AA-), as such a downgrade would raise the cost of capital for the issuer (Kedia et al. 2017; Kraft 2015). ${ }^{12}$

\footnotetext{
${ }^{8}$ As suggested by Sean Egan, founder of EJR, agencies in the investor-paid model do not have access to inside information from the issuers (EJR 2008). On the other hand, a key role of issuer-paid ratings is to provide private information to the capital markets such that "paying for ratings may allow firms to incorporate inside information into the assigned ratings without disclosing details to the public at large" (Kliger and Sarig 2000; p. 2879).

9 For instance, the combined number of credit analysts and their supervisors employed by EJR was 17 (23) in 2018 (2019). In comparison, 1714 (1732), 1557 (1559), and 1269 (1277) credit analysts worked for Moody's, S\&P, and Fitch in 2018 (2019), respectively (SEC 2020c, d).

10 Such as: Sarbanes-Oxley Act from 2002, Credit Rating Agency Reform Act from 2006, and especially Dodd-Frank Wall Street Reform Act from 2010

11 Several studies, such as Poon (2003) and Poon et al. (2009), have expressed their concerns about the possible downward bias in unsolicited (non-issuer-paid) ratings. The argument of self-interest incentive in investor-paid CRAs differs from the argument of catering to investors in Tang et al. (2020).

12 By the same token, an issuer with Moody's upside threshold rating (e.g., A1) is more likely to be upgraded to a higher broad rating category (e.g., Aa2) than an issuer with EJR's corresponding upside threshold ratings, as such an upgrade would reduce the cost of capital for the rated issuer.
} 
Our second hypothesis is related to the dynamics of the rating changes given by the agencies in two business models, focusing on the rating grades that involve the interests of issuers. It is more likely that conflict of interest with issuers arises in the threshold rating grades. The conflict-of-interest argument suggests that issuer-paid CRAs tend to please issuers (e.g., Baghai and Becker 2018; Efing and Hau 2015; He et al. 2012; Kedia et al. 2017). Therefore, issuers with threshold ratings may receive more favorable treatments from issuer-paid CRAs than from investor-paid agencies.

H2 (conflict of interest in issuer-paid CRAs): Downside (upside) threshold issuerpaid ratings are less (more) likely to be downgraded (upgraded) than the corresponding investor-paid ratings.

\section{Method and data}

\section{Methodology}

Quah (1993) first proposes the DDA to investigate the transitional dynamics of distribution with regards to the country's economic growth. This approach poses several advantages in the study of credit rating distribution. First, it is notable that existing empirical studies are based on econometric analysis ${ }^{13}$; however, the output of the regression model is a numerical value only. Thus, it is impossible to employ econometric analysis to investigate the shape of a distribution that is a two-dimensional entity. Second, the DDA can show the shape of the distribution in detail and across time. Third, this approach not only can predict the future distribution shape but also can provide important information on the transition of the entities within the distribution, that is, how one variable of the distribution behaves regarding another variable. Consequently, the probability of moving up and down inside the distribution can be derived accordingly.

The DDA can be broadly divided into two major types: the traditional Markov transition matrix analysis and the stochastic kernel approach. Some studies employ various Markov chain models to examine credit rating migration dynamics (e.g., Frydman and Schuermann 2008) and their structural breaks which are attributable to the state of the economy (Xing et al. 2012, 2020). However, these studies are rare and focus exclusively on the ratings produced by the issuer-paid CRA-S\&P. Furthermore, the Markov transition matrix has a major shortcoming as the demarcation of the state associated with the selection of grid values is an arbitrary process. Therefore, the results largely depend on the grid line selection approach. Conversely, the stochastic kernel approach is deemed to be much better as it can satisfactorily circumvent this issue; thus, it is employed in the present study (e.g., Johnson 2005; Wu and He 2017). The bivariate kernel estimator is defined below in Eq. (1).

$$
\widehat{f}(x, y)=\frac{1}{n h_{1} h_{2}} \sum_{i=1}^{n} K\left(\frac{x-X_{i, t}}{h_{1}}, \frac{y-X_{i, t+1}}{h_{2}}\right)
$$

\footnotetext{
${ }^{13}$ We refer to studies on corporate credit ratings. However, it is worth mentioning that alternative non-econometric approaches are used in the strand of literature on personal credit risk and credit scoring models. For instance, using a large sample of Chinese personal loans, Shen et al. (2020) employ a three-stage learning framework based on an unsupervised transfer machine learning technique on credit scoring.
} 
where $n$ is the number of observations, $h_{1}$ and $h_{2}$ are the bandwidths which are calculated based on the approach proposed by Silverman (1986), $K$ is the normal density function, $x$ is a variable representing the rating of an issuer at time $t, y$ is a variable representing the rating of that issuer at time $t+1, X_{i, t}$ is an observed value of rating at time $t$, and $X_{i, t+1}$ is the observed rating value at time $t+1$. Assuming that the process is firstorder and time-invariant, the distribution at time $t+\tau$ depends not on any previous distributions but on $t$ only; thus, the distributions at time $t+\tau$ can be represented by Eq. (2).

$$
f_{t+\tau}(z)=\int_{0}^{\infty} g_{\tau}(z \mid x) f_{t}(x) d x
$$

where $f_{t+\tau}(z)$ is the $\tau$-period-ahead density function of $\mathrm{z}$ conditional on $x, g_{\tau}(z \mid x)$ is the transition probability kernel which maps the distribution from time $t$ to $t+\tau$, and $f_{t}(x)$ is the kernel density function of the distribution of rating at time $t$. This approach is widely applied in various research areas, such as industrial output (Cheong and Wu 2018), urban and rural household income ( $\mathrm{Li}$ and Cheong 2016; Shen et al. 2021), city size (Wu and He 2017), and even carbon dioxide emissions (Cheong et al. 2016; Wu et al. 2016). To the best of our knowledge, this is the first attempt to study the transitional dynamics of credit ratings, with regards to both issuer- and investor-paid rating models, and apply the stochastic kernel approach in estimating the downgrade and upgrade probabilities of credit ratings.

An adaptive kernel with flexible bandwidth is employed in the present study to consider the sparseness of the data (Silverman 1986). In this process, the rating value of each issuer is transformed into a relative one by dividing an issuer's rating by the average yearly rating, and the transition probability kernel is constructed based on these relative values. Therefore, the axes of the contour map and the three-dimensional plot are measured in a relative sense, and the relative value of one corresponds to the mean, while the relative value larger than one indicates that the rating is larger than the mean, and the relative value smaller than one indicates that the rating is smaller than the mean. To better reveal the transitional dynamics of a credit rating of an issuer, the downgrade probability, $p^{d}(x)$, and upgrade probability, $p^{u}(x)$, are computed given the prevailing credit rating of $x$ in Eqs. (3) and (4), respectively, as follows:

$$
\begin{aligned}
& p^{d}(x)=\int_{0}^{x} g_{\tau}(z \mid x) d z \\
& p^{u}(x)=\int_{x}^{\infty} g_{\tau}(z \mid x) d z
\end{aligned}
$$

The downgrade (upgrade) probability is the probability of a rating of an issuer in the next period that is lower (greater) than its current rating. As the sum of the downgrade and upgrade probabilities is equal to one, the downgrade probability is equal to one minus the upgrade probability. This implies that when the downgrade probability of a rating is higher, its upgrade probability will be lower, and vice versa.

The DDA is very powerful and unique to study the transitions of the credit rating of an issuer over time. Thus, the DDA constitutes a novel contribution to the existing 
empirical literature as it provides a comprehensive view on the full spectrum of rating grades ranging from investment grade to speculative grade and allows us to compare the transitions of the ratings of two business models over time.

\section{Data and sample}

In the present study, we compare the transitional dynamics of investor- and issuer-paid ratings in the U.S. The whole database is separated into these two groups and distribution dynamics analysis is conducted individually for each of them. Thereafter, comparisons are made for these two groups and conclusions are drawn according to the findings. The issuer-paid CRA adopted in the present study is Moody's, which is one of the Big Three CRAs in the U.S. and global rating market. We obtain the issuer ratings from Moody's Default and Recovery Database. Egan-Jones Ratings Company is the only NRSRO operating solely under the investor-paid model. The EJR rating data are extracted from Bloomberg and cover from 2011 to $2018 .^{14}$

Moody's generates a 21-point scale to indicate issuers from the most creditworthy (rated as Aaa) to the least creditworthy (rated as C). However, EJR uses a similar 22-point scale that ranges from the most creditworthy rating (AAA) to the least creditworthy rating (D) indicating a "Default". Following the previous literature, (Beaver et al. 2006; Poon and Shen 2020; Xia 2014), we convert the letter ratings into numerical values, such that a larger numerical value indicates a better rating, i.e., Aaa/AAA $=22$, Aa1/ $\mathrm{AA}+=21, \ldots, \mathrm{C} / \mathrm{C}=2$, and $\mathrm{D}=1$ (for the full spectrum of this conversion see Table 7 of Appendix). ${ }^{15,16}$

The sample is restricted to all available (750) U.S. issuers rated by both Moody's and EJR from July 2011 to December 2018. We collect monthly data on the ratings issued by Moody's and EJR for each issuer. ${ }^{17}$ Table 1 presents the number of issuers and monthly ratings by year in the sample. It also provides the average ratings on the issuers by year given by Moody's and EJR. We can observe that the average ratings in the overall sample are 13.20 (Moody's) and 13.86 (EJR), corresponding to letter ratings between Baa2 and Baa3 (BBB and BBB-). The average annual ratings from both agencies are relatively similar, although ratings assigned by EJR remain consistently higher with the annual difference fluctuating from 0.54 notches in 2016 and 2017 to 0.83 notches in 2011 . We use the average yearly ratings in the sample to calculate the monthly relative credit ratings (RCRs) of each issuer and the transition probability kernel. Thereafter, we map the RCRs to their corresponding numerical and letter ratings. Thus, the RCR of $1(R C R=1)$

\footnotetext{
${ }^{14}$ As an investor-paid CRA, EJR only disseminates its ratings and rating reports to its subscribers. After June 2011, EJR ratings have also been released in Bloomberg. Our sample is thus limited by the data availability of EJR ratings. The advantage of using the sample is that we can compare the rating performance from issuer- and investor-paid CRAs after the Dodd-Frank Act when the potential conflict of interest in the issuer-paid model is mitigated. Setting the rating sample after the Dodd-Frank Act allows us to focus on the self-interest motivation in the investor-paid CRA (EJR).

15 EJR provides issuer ratings to public firms only. Moody's assigns issuer credit ratings to both public and private firms. The D grade rating is assigned by EJR ex-post a firm's default. We exclude the D grade ratings from the sample in comparing the rating performance between two agencies as Moody's does not assign such a grade.

16 The Big Three credit rating agencies, that is, Moody's, S\&P, and Fitch, adopt a similar rating system to describe the creditworthiness of issuers from excellent to poor. The letters assigned could be slightly different, for instance, Aaa in Moody's and AAA in S\&P. However, ratings of the same grade (e.g., Baa3 and BBB-) are accepted equivalently by market participants.

17 We focus our analysis on the comparison between ratings issued by Moody's and EJR. Extant empirical literature (Bonsall 2014; Bonsall et al. 2017; Dichev and Piotroski 2001) consider two major issuer-paid CRAs, S\&P and Moody's, as relatively homogenous and reasonable substitutes.
} 
Table 1 The number of firms/firm-month observations and average ratings by year

\begin{tabular}{|c|c|c|c|c|c|c|}
\hline Year & $\mathrm{N}$ of firms & $\mathrm{N}$ of ratings & Rating & Moody's & EJR & Moody's-EJR \\
\hline 2011 & 455 & 2,345 & & 13.14 & 13.97 & -0.83 \\
\hline 2012 & 546 & 5,940 & & 13.12 & 13.82 & -0.7 \\
\hline 2013 & 582 & 6,602 & & 13.08 & 13.72 & -0.64 \\
\hline 2014 & 615 & 6,766 & & 13.19 & 13.98 & -0.79 \\
\hline 2015 & 605 & 6,984 & & 13.23 & 13.87 & -0.64 \\
\hline 2016 & 620 & 6,876 & & 13.11 & 13.65 & -0.54 \\
\hline 2017 & 564 & 6,493 & & 13.28 & 13.82 & -0.54 \\
\hline 2018 & 534 & 6,229 & & 13.42 & 14.03 & -0.61 \\
\hline Total & 4521 & 48,235 & Average & 13.20 & 13.86 & -0.66 \\
\hline
\end{tabular}

This table reports the average number of firms and firm-month ratings in the sample. We also report the average ratings given by Moody's and EJR each year

corresponds to letter ratings between Baa2 and Baa3 (Moody's) or BBB and BBB- (EJR). Likewise, the RCR of 0.9599 ( $R C R=0.9599)$ corresponds to Baa3 (Moody's) or BBB(EJR). Similarly, the RCR of 1.0337 is converted to Baa2 (Moody's) or BBB (EJR). The complete conversion scale can be found in Table 7 of Appendix. ${ }^{18}$

Table 2 presents the credit ratings of the issuers given by Moody's and EJR in each rating grade. For issuers in each EJR rating grade, we calculate the average monthly ratings from Moody's and the rating difference between EJR and Moody's ratings. Table 2 shows that in the range from BB to AAA, EJR's ratings are higher than Moody's ratings, while EJR assigns lower ratings than Moody's below the grade B-. Overall, the average ratings on the issuers given by EJR are higher than the ratings given by Moody's by approximately 0.66 notches. More specifically, EJR rates issuers around 0.93 notches above Moody's within the investment grade but assigns similar ratings as Moody's in the speculative grade. Seemingly, the results from the raw analysis do not support the claim that issuer-paid CRAs, such as Moody's, inflate issuer ratings. The results are consistent with a recent study conducted by Toscano (2020), who finds that S\&P (issuer-paid) ratings are lower than EJR (investor-paid) ratings in the post-Dodd-Frank period.

\section{Results and discussion}

The results of the distribution dynamics of credit ratings by EJR and Moody's from 2011 to 2018 are presented graphically by three-dimensional plots and their corresponding contour maps in Figs. 1 and 2, respectively. The contour maps (Fig. 2) exhibit a bird's-eye view of the three-dimensional plot. These two types of display tools are commonly used in the analysis of distribution dynamics.

The contour maps in Fig. 2 show the stochastic transitional probability kernels of the RCR by both CRAs from 0.3 to 1.6 (equivalent to CCC- to AAA by EJR or Caa3 to Aaa by Moody's) in the study period (2011-2018). This indicates that there is a wide spectrum of issuers rated by EJR and Moody's, and the range of credit ratings of issuers

\footnotetext{
18 We follow the conventions in the credit rating literature (e.g., Beaver et al. 2006; Poon et al. 2017; Poon and Shen 2020; Xia 2014) and convert a letter grade to its corresponding numerical value in a linear scale. Our findings, however, are unaffected by this conversion method as the analysis is based on relative credit ratings. The DDA focuses on the transitions between states (relative ratings); thus, the probability of mobility is essentially estimated from the ranking of ratings. We thank a referee for raising the concern on the linear rating conversion.
} 
Table 2 The average ratings of Moody's and EJR by rating category

\begin{tabular}{|c|c|c|c|}
\hline EJR rating letter & Moody's & EJR & Moody's-EJR \\
\hline AAA & 19.87 & 22 & -2.13 \\
\hline $\mathrm{AA}+$ & 19.78 & 21 & -1.22 \\
\hline AA & 18.85 & 20 & -1.15 \\
\hline$A A-$ & 17.38 & 19 & -1.62 \\
\hline$A+$ & 16.52 & 18 & -1.48 \\
\hline A & 15.74 & 17 & -1.26 \\
\hline A- & 14.92 & 16 & -1.08 \\
\hline $\mathrm{BBB}+$ & 14.15 & 15 & -0.85 \\
\hline BBB & 13.58 & 14 & -0.42 \\
\hline BBB- & 12.74 & 13 & -0.26 \\
\hline $\mathrm{BB}+$ & 11.67 & 12 & -0.33 \\
\hline BB & 10.73 & 11 & -0.27 \\
\hline $\mathrm{BB}-$ & 10.06 & 10 & 0.06 \\
\hline $\mathrm{B}+$ & 8.91 & 9 & -0.09 \\
\hline B & 7.91 & 8 & -0.09 \\
\hline$B-$ & 6.94 & 7 & -0.06 \\
\hline $\mathrm{CCC}+$ & 6.95 & 6 & 0.95 \\
\hline $\mathrm{CCC}$ & 6.05 & 5 & 1.05 \\
\hline $\mathrm{CCC}-$ & 4.73 & 4 & 0.73 \\
\hline $\mathrm{CC}$ & 5.93 & 3 & 2.93 \\
\hline C & 3.98 & 2 & 1.98 \\
\hline All & 13.20 & 13.86 & -0.66 \\
\hline Investment grade & 14.85 & 15.77 & -0.93 \\
\hline Speculative grade & 9.51 & 9.52 & -0.01 \\
\hline
\end{tabular}

This table reports the average firm-month rating from Moody's and EJR in the rating category of EJR. That is, for the firms (issuers) in each EJR rating grade, we compute the average ratings from Moody's issued to those firms. The last column reports the rating differences between Moody's and EJR. We also report the average ratings and rating differences in the overall sample, investment grade and speculative grade samples

rated by both CRAs are approximately the same in the study period. The contour map indicates the probability distribution of the RCR in month $t+1$ (on the vertical axis) for each RCR in month $t$ (on the horizontal axis). The credit rating might migrate upward or downward in the next period.

Given the transition probability kernel of the RCR in Fig. 2, the downgrade and upgrade probabilities ${ }^{19}$ of the issuer in period $t+1$ for a numerical credit rating in period $t$ are computed and presented in Figs. 3 and 4, respectively. Thus, Figs. 3 and 4 show the downgrade and upgrade probability plots for the numerical credit ratings assigned by EJR and Moody's. It is found that regardless of the business model adopted, the higher the credit rating of an issuer, the lower (higher) the upgrade (downgrade) probability, and vice versa.

However, the differences in the probabilities of a downgrade and upgrade for particular rating grades between two types of rating models is noteworthy. First, EJR's ratings have much larger downgrade probabilities and smaller upgrade probabilities than Moody's

\footnotetext{
${ }^{19}$ From month $t$ to $t+1$, the credit rating of a firm may either be downgraded or upgraded by a CRA. Given a probability distribution in month $t+1$, the upgrade probability from $t$ to $t+1=1$ - downgrade probability from $t$ to $t+1$. In other words, a higher downgrade probability implies a lower upgrade probability.
} 


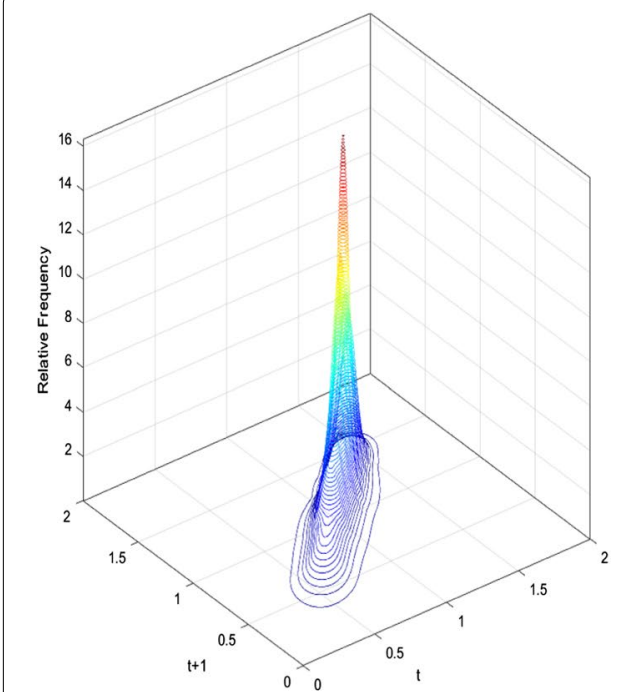

(Panel A: EJR)

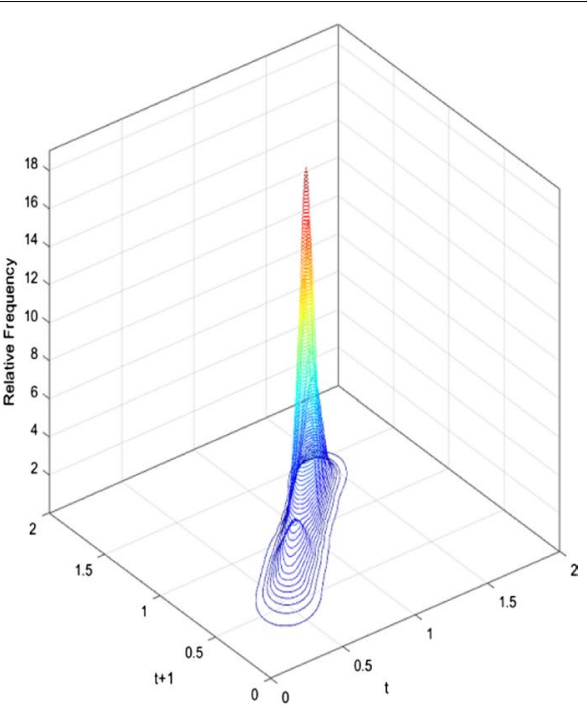

(Panel B: Moody's)

Fig. 1 Three-dimensional plot of transition probability kernel for relative credit ratings assigned by EJR and Moody's from 2011 to 2018

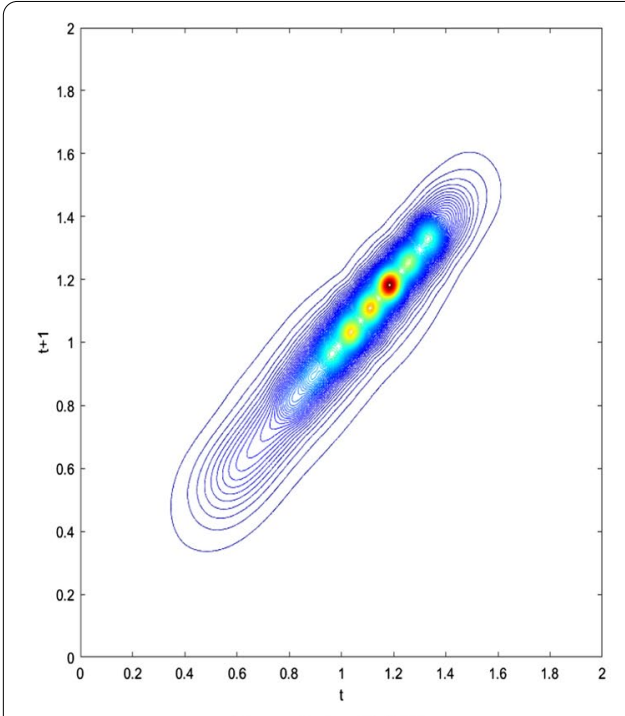

(Panel A: EJR)

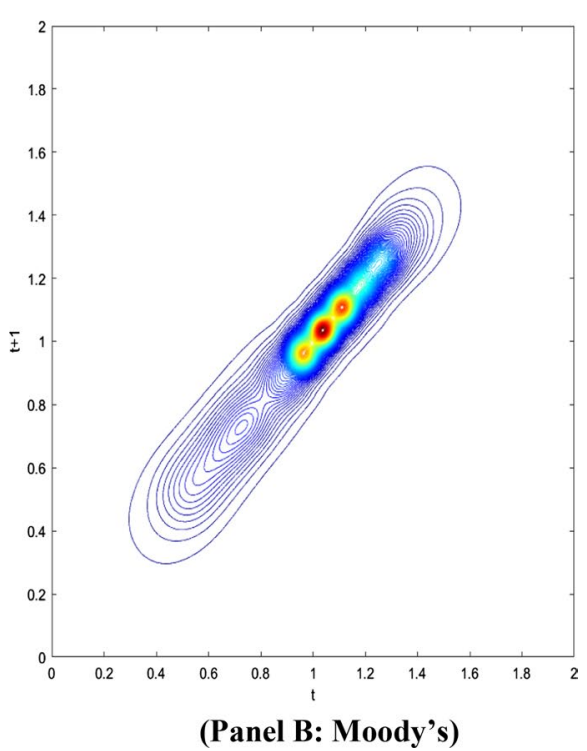

(Panel B: Moody's)

Fig. 2 Contour map of transition probability kernel for relative credit ratings assigned by EJR and Moody's from 2011 to 2018

ratings in the rating grade of $\mathrm{CCa} 2 / \mathrm{CCC}$ and below, that is, the range of numerical credit ratings from 5 to 2 . Second, in the rating grade $\mathrm{A} 1 / \mathrm{A}+$ (corresponding to a numerical value of 18), Moody's ratings have higher downgrade and lower upgrade probabilities than EJR's ratings. The probabilities of rating changes in other grades are similar for both rating agencies.

Next, we compute the specific differences of downgrade and upgrade probabilities between EJR and Moody's ratings to compare the investor- and issuer-paid rating 


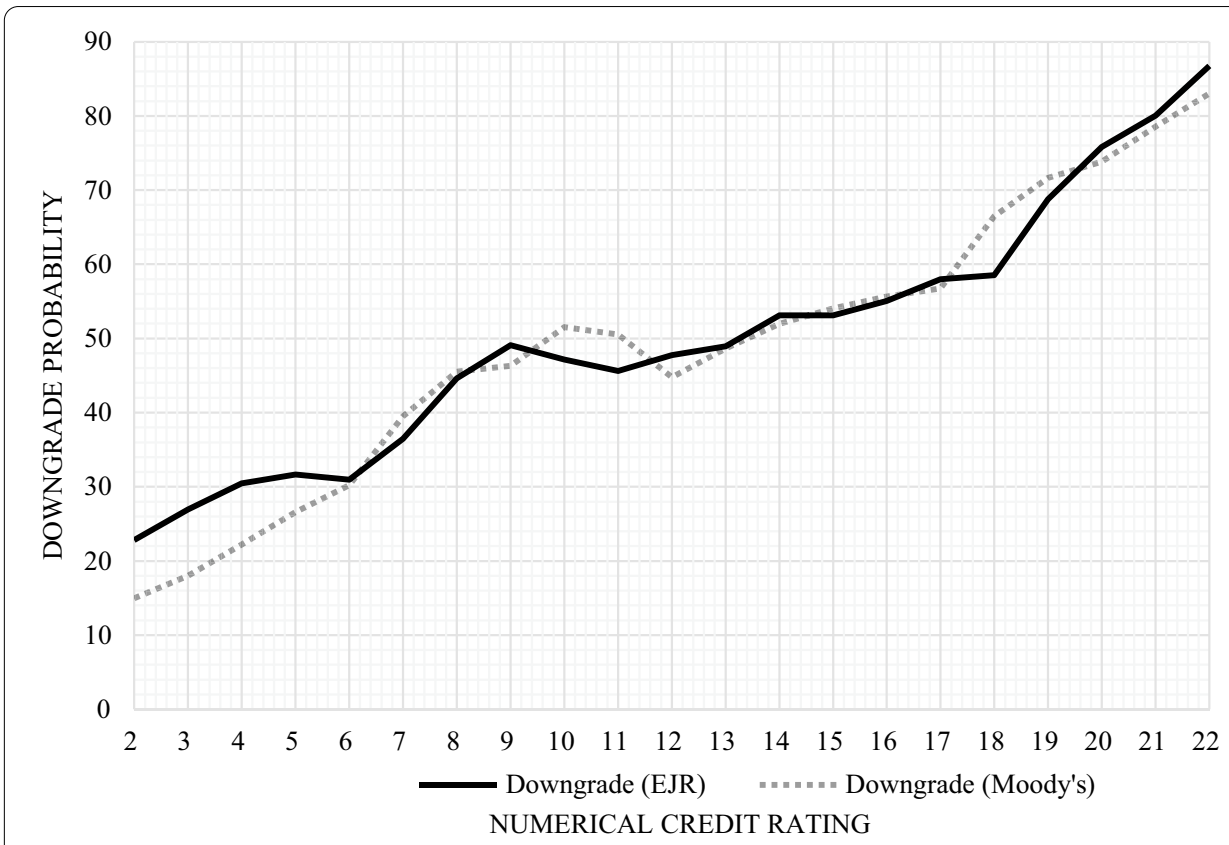

Fig. 3 Downgrade probability plots for numerical credit ratings assigned by EJR and Moody's, from 2011 to 2018

changes. Table 3 shows that the average difference of downgrade (and upgrade ${ }^{20}$ ) probabilities between Moody's and EJR rating grades is only $1 \%$. However, for all rating grades close to default, except Caa1/CCC-, the differences of downgrade probabilities between EJR and Moody's ratings are greater than 5\%, i.e., EJR's downgrade probabilities are significantly larger than Moody's.

In the unreported results, we run a significance test on the differences of downgrade probabilities from Moody's and EJR's ratings. ${ }^{21}$ We gather the data from the kernel estimator and then pool the rating values and the downgrade probabilities of ratings assigned by EJR and Moody's. A binary dummy variable (EJR), which is equal to one if the probabilities of a downgrade are estimated from EJR's ratings, is constructed. We regress the probabilities of the downgrade from the kernel estimator on rating values (RATING), EJR rating dummy (EJR), and their interaction term.

The results show that the downgrade probabilities significantly increase with credit ratings assigned by both Moody's and EJR, which is consistent with the overall trends depicted in Fig. 3. The downgrade probabilities of EJR's ratings are smaller (larger) in high-rating (low-rating) issuers than those in Moody's ratings. The coefficient on the interaction term is highly significant, thereby suggesting that the differences in the downgrade probabilities between Moody's and EJR are statistically significant. The results from this significance test are again consistent with our findings from Fig. 3

\footnotetext{
${ }^{20}$ As the sum of the downgrade and upgrade probabilities is equal to one, the downgrade probability is equal to one minus the upgrade probability. For example, the downgrade probability of EJR's A rating equals to 0.52 or $52 \%$ (1-0.58).

21 We appreciate the significance test suggestion from one referee. For brevity, those results are not tabulated, but they are available upon request.
} 


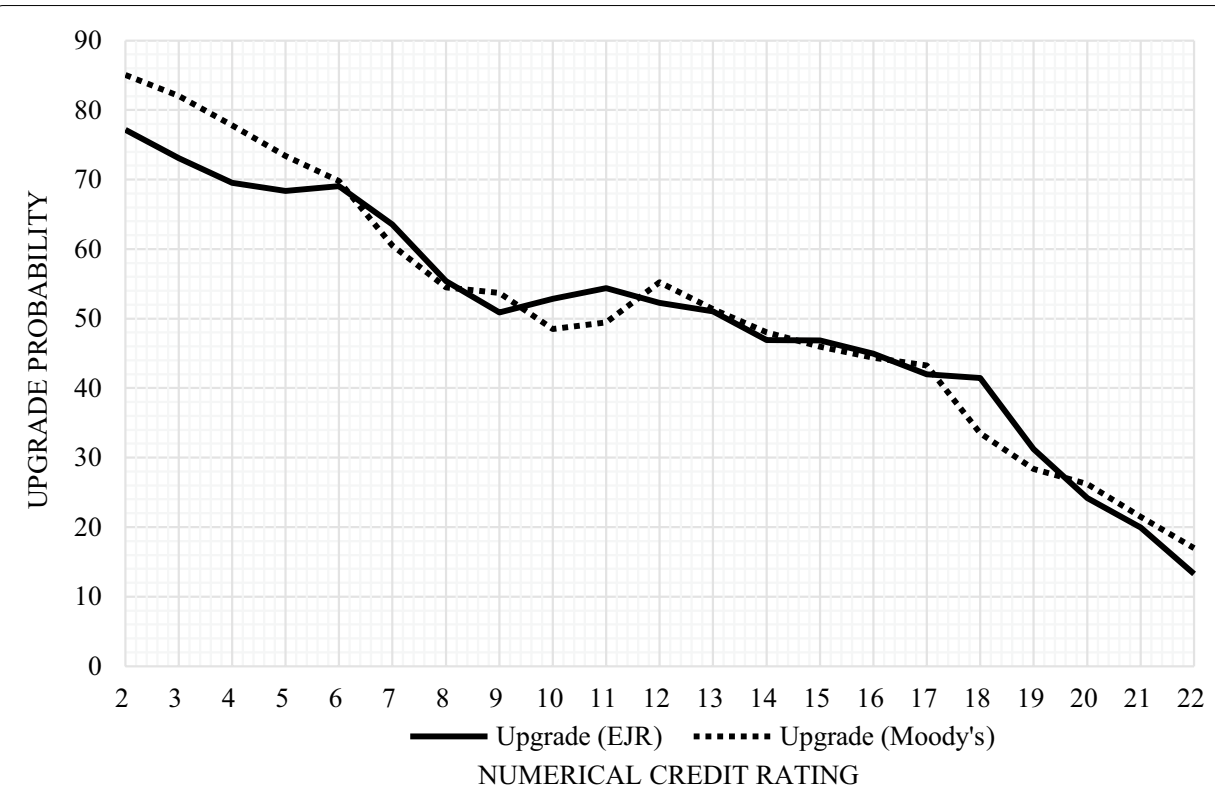

Fig. 4 Upgrade probability plots for numerical credit ratings assigned by EJR and Moody's, from 2011 to 2018

that EJR is more likely to downgrade issuers in the potentially defaulting grades than Moody's.

There are two possible explanations for the findings: first, Moody's is reluctant to downgrade issuers because 2they are paid by them. If it is less likely for Moody's to downgrade issuers than for EJR (owing to the conflict of interest with the issuers), then the downgrade probabilities for Moody's ratings should be generally lower than those for EJR's ratings across different rating grades. This explanation, however, may not be valid for issuers with higher rating grades, that is, rating grades above $\mathrm{Caa} 1 / \mathrm{CCC}+$, and the downgrade probabilities of EJR's ratings are not consistently higher than those of Moody's ratings. In fact, for Aa3/AA-, A1/A+, Ba2/BB, Ba3/BB-, and B3/B- grades, the downgrade probabilities of EJR's ratings are much lower (on average, approximately $4.63 \%$ in these five rating grades) than those of Moody's ratings.

Instead, we argue that the findings are consistent with our first hypothesis that EJR exhibits a harsher attitude than Moody's toward potentially defaulting issuers, even though these issuers do not eventually default. ${ }^{22}$ In our sample, there are only nine issuers (approximately 1.2\%) out of 750 that have defaulted during the sample period. This suggests that higher downgrade probabilities in the rating grades below B- by EJR are overly conservative to issuers with poor creditworthiness. Consequently, this could ensue at the cost of false warnings, that is, assigning lower speculative grade ratings to issuers that do not default subsequently (De Haan 2017; Cornaggia and Cornaggia 2013).

\footnotetext{
${ }^{22}$ Alternatively, EJR may assign overly lenient initial ratings, and thus, it is more likely to downgrade firms subsequently. We test this explanation by exploring: (1) whether initial ratings, especially those in the speculative grades, are higher than subsequent ratings in the EJR ratings; (2) whether rating differences between Moody's and EJR are significantly different in initial ratings and subsequent ratings; and (3) whether EJR ratings are less responsive to default risk in the initial ratings than in the subsequent ratings. The results from the three sets of tests do not support this argument. These results are not reported, but they are available upon request. We appreciate a referee that suggested this alternative explanation.
} 
Table 3 Downgrade probability of Moody's and EJR's ratings

\begin{tabular}{|c|c|c|c|c|}
\hline \multirow[t]{2}{*}{ Moody's } & \multirow[t]{2}{*}{ EJR's } & \multicolumn{3}{|c|}{ Downgrade probability (\%) } \\
\hline & & Moody's & EJR & Moody's-EJR \\
\hline Aaa & AAA & 83.03 & 86.74 & -3.71 \\
\hline Aa1 & $\mathrm{AA}+$ & 78.53 & 80.05 & -1.52 \\
\hline $\mathrm{Aa} 2$ & $\mathrm{AA}$ & 73.81 & 75.81 & -2.00 \\
\hline Aa3 & AA- & 71.65 & 68.78 & 2.87 \\
\hline $\mathrm{A} 1$ & $\mathrm{~A}+$ & 66.50 & 58.54 & 7.96 \\
\hline$A 2$ & A & 56.75 & 58.00 & -1.25 \\
\hline A3 & A- & 55.62 & 55.06 & 0.56 \\
\hline Baa1 & $\mathrm{BBB}+$ & 54.06 & 53.12 & 0.94 \\
\hline Baa2 & BBB & 51.95 & 53.10 & -1.15 \\
\hline Baa3 & $\mathrm{BBB}-$ & 48.66 & 48.95 & -0.29 \\
\hline Ba1 & $\mathrm{BB}+$ & 44.78 & 47.73 & -2.95 \\
\hline $\mathrm{Ba} 2$ & $\mathrm{BB}$ & 50.54 & 45.63 & 4.91 \\
\hline $\mathrm{Ba} 3$ & BB- & 51.52 & 47.16 & 4.36 \\
\hline B1 & $B+$ & 46.30 & 49.10 & -2.80 \\
\hline B2 & B & 45.51 & 44.62 & 0.89 \\
\hline B3 & $B-$ & 39.50 & 36.46 & 3.04 \\
\hline Caa1 & $\mathrm{CCC}+$ & 30.21 & 30.97 & -0.76 \\
\hline Caa2 & $\mathrm{CCC}$ & 26.60 & 31.66 & -5.06 \\
\hline Caa3 & $\mathrm{CCC}-$ & 22.20 & 30.47 & -8.27 \\
\hline $\mathrm{Ca}$ & CC & 17.99 & 26.94 & -8.95 \\
\hline \multirow[t]{2}{*}{ C } & C & 14.96 & 22.84 & -7.88 \\
\hline & & & Average & -1.00 \\
\hline
\end{tabular}

Notably, EJR has incentives to underrate potentially defaulting issuers because of more significant legal penalties or substantial reputation losses for the missed defaults than false warnings.

We then focus on comparing the probabilities of downgrades and upgrades in the so-called threshold ratings between Moody's and EJR to test our second hypothesis. Because of the potential conflict of interest, issuer-paid CRAs are accused of providing overly favorable rating treatments to issuers (clients), particularly those with threshold ratings (Kedia et al. 2017). The two most important threshold ratings are Baa3/BBBand $\mathrm{Baa} / \mathrm{BB}+$, which are the ratings around the boundary between investment grade and speculative grade. For downside threshold ratings, that is, ratings with a minus sign (especially Baa3/BBB-), a downgrade to lower (speculative) major rating category incurs significantly higher costs (and much smaller pool) of capital for the issuers (Kisgen 2006). By the same token, for upside threshold ratings, that is, ratings with a plus sign (especially Baa1/BB+), issuer-paid ratings are more likely to be upgraded to higher (and investment) major rating category than investor-paid ratings-this entails significantly lower costs (greater pool) of capital for upgraded issuers. Thus, the conflict of interest with issuers suggests that issuer-paid ratings in these thresholds are less (more) likely to be downgraded (upgraded) than the same thresholds in investor-paid ratings.

Panel A of Table 4 reports the issuers with such downside threshold ratings. In general, Moody's ratings are more likely to be downgraded than EJR's ratings in the threshold ratings $\mathrm{Aa} 3 / \mathrm{AA}-, \mathrm{A} 3 / \mathrm{A}_{-}, \mathrm{Ba} 3 / \mathrm{BB}-$, and $\mathrm{B} 3 / \mathrm{B}$. For the issuers with Baa3/ 
BBB-, Moody's rating is less likely to be downgraded to speculative grade than EJR's rating, but the difference of downgrade probability is only $0.29 \%$. It appears that even though Moody's may have strong incentives to withhold the downgrade of a firm from Baa3 to Ba1 (across the boundary of investment grade versus speculative grade), owing to its business model, the insignificant difference in downgrade probabilities between Moody's and EJR indicates that in practice Moody's does not (or cannot) favor more the issuers with Baa3 grade rating in comparison with EJR. This finding is surprising as previous studies assume that issuer-paid CRAs would provide overly favorable ratings to delay or avoid downgrades, especially across the investment-speculative boundary (Baghai and Becker 2018; Kedia et al. 2017; Kraft 2015). The results suggest that Moody's is more likely to downgrade the issuers with the investment grade threshold ratings than EJR. For instance, the downgrade probability from Aa3 by Moody's is $2.87 \%$ higher than from the corresponding threshold rating AA- by EJR. Furthermore, only for the issuers with near-default grade threshold ratings, Moody's Caa3 rating is much less likely $(8.27 \%)$ to be downgraded than the corresponding EJR's CCC - rating. However, as we discussed above, the difference could be due to the overly harsh ratings given by EJR instead of the overly favorable ratings assigned by Moody's. Thus, there is no consistent evidence to support our second hypothesis. Summarily, the results from the novel DDA to issuer credit ratings from two different models (issuer-paid versus investor-paid) provide findings that have not been documented in the previous studies and thus constitute a novel contribution to the extant literature on ratings.

Panel B of Table 4 reports the upgrade probabilities for the issuers with upside threshold ratings. In four out of six of such ratings $(\mathrm{Aa} 1 / \mathrm{AA}+, \mathrm{Ba} 1 / \mathrm{BB}+, \mathrm{B} 1 / \mathrm{B}+$, and $\mathrm{Caa} 1 /$ $\mathrm{CCC}+$ ), issuer-paid ratings are more likely to be upgraded than investor-paid ratings, but the differences in the upgrade probabilities of Moody's and EJR's ratings are relatively small, between $0.76 \%$ and $2.95 \%$. However, for issuers rated as A1/A+ and Baa1/ $\mathrm{BBB}+$, Moody's ratings are less likely to be upgraded than EJR's ratings and the differences between upgrade probabilities are $0.94 \%$ and $7.97 \%$, respectively. Again, there is no consistent and solid evidence to support the second hypothesis. In sum, these findings may suggest that to maintain a reputation for long-term success in the rating industry with stricter regulatory requirements and greater investor scrutiny in the post-DoddFrank period (2011-2018), issuer-paid CRAs, such as Moody's, do not generally provide biased ratings in favor of issuers with threshold ratings.

Next, we conduct additional analyses to test our hypotheses. The results presented above show that EJR is more likely to downgrade issuers with ratings equal to or below Caa1/CCC+than Moody's. If EJR's ratings could capture the creditworthiness of the firm accurately, the higher downgrade probabilities in the lower rating grades would allow EJR to avoid missed defaults. We examine whether EJR is more likely to have fewer missed defaults than Moody's. Because NRSRO CRAs rate exclusively large U.S. corporations, the historical defaults by 750 sampled corporations in the post-crisis 
Table 4 Probabilities of rating changes in threshold ratings

\begin{tabular}{|c|c|c|c|c|}
\hline \multicolumn{2}{|c|}{ Rating letter grades } & \multicolumn{3}{|c|}{ Downgrade probability (\%) } \\
\hline Moody's & EJR & Moody's & EJR & Moody's -EJR \\
\hline \multicolumn{5}{|c|}{ Panel A: Downgrade probability of Moody's and EJR's ratings designated with a minus sign } \\
\hline Aa3 & AA- & 71.65 & 68.78 & 2.87 \\
\hline A3 & A- & 55.62 & 55.06 & 0.56 \\
\hline Baa3 & BBB- & 48.66 & 48.95 & -0.29 \\
\hline $\mathrm{Ba3}$ & BB- & 51.52 & 47.16 & 4.36 \\
\hline B3 & B- & 39.50 & 36.46 & 3.03 \\
\hline \multirow[t]{2}{*}{ Caa3 } & $\mathrm{CCC}-$ & 22.20 & 30.47 & -8.27 \\
\hline & & & Average & 2.11 \\
\hline \multicolumn{2}{|c|}{ Rating letter grades } & \multicolumn{3}{|c|}{ Upgrade probability (\%) } \\
\hline Moody's & EJR & Moody's & EJR & Moody's -EJR \\
\hline \multicolumn{5}{|c|}{ Panel B: Upgrade probability of Moody's and EJR's ratings designated with a plus sign } \\
\hline Aa1 & $\mathrm{AA}+$ & 21.47 & 19.95 & 1.52 \\
\hline A1 & $A+$ & 33.50 & 41.46 & -7.97 \\
\hline Baa1 & $\mathrm{BBB}+$ & 45.94 & 46.88 & -0.94 \\
\hline Ba1 & $\mathrm{BB}+$ & 55.22 & 52.27 & $\begin{array}{l}2.95 \\
2.95\end{array}$ \\
\hline B1 & $B+$ & 53.70 & 50.90 & 2.80 \\
\hline \multirow[t]{2}{*}{ Caa 1} & $\mathrm{CCC}+$ & 69.79 & 69.03 & $\begin{array}{l}0.76 \\
0.76\end{array}$ \\
\hline & & & Average & -0.15 \\
\hline
\end{tabular}

Dodd-Frank period is small and equal to 31. Furthermore, neither EJR nor Moody's have missed any of the 31 defaults. ${ }^{23}$

Table 5 reports the average ratings given by EJR and Moody's in 12 months before the defaults took place. Both CRAs assign Caa1/CCC+or below to an issuer that subsequently defaults within one year. Averagely, Moody's assigns slightly higher ratings to the same issuers. The difference between ratings by Moody's and EJR in any of 12 months before the default is less than one notch and ranges from -0.13 (six months before) to 0.65 (one month before). The results indicate that although EJR is more likely to downgrade issuers in low rating grades than Moody's, both agencies have similar rating performance/timing in avoiding missed defaults. In other words, EJR's harsher attitude toward issuers in the low rating grades tend to produce more false warnings to market participants, that is, underrating an issuer that has not defaulted within one year. Such results deliver additional support in favor of our first hypothesis.

We also conduct further tests on the rating performance between Moody's and EJR based on actual rating changes. Following previous studies (e.g., Beaver et al. 2006), we run Granger causality tests between rating changes by Moody's and EJR. The untabulated results ${ }^{24}$ show that the lead-lag relationship of rating changes between Moody's and EJR is bi-directional between 2011 and 2018, indicating that EJR does

\footnotetext{
${ }^{23}$ NRSRO CRAs do not generally assess the default risk of small and medium-sized enterprises (SMEs) as SMEs have restricted access to the bond market. This is unfortunate given that SMEs are the backbone of every country's economy, although their default risk is generally much higher compared with large corporations (Kou et al. 2021).

24 For the sake of brevity, the results are not tabulated, but they are available from the authors upon request.
} 
Table 5 Ratings given by Moody's and EJR before defaults

\begin{tabular}{llcc}
\hline Month before default & Moody's & EJR & Moody's-EJR \\
\hline 1 & 3.44 & 2.79 & 0.65 \\
2 & 3.64 & 3.18 & 0.46 \\
3 & 3.76 & 3.67 & 0.09 \\
4 & 3.96 & 3.96 & 0.00 \\
5 & 4.27 & 4.33 & -0.06 \\
6 & 4.41 & 4.54 & -0.13 \\
8 & 4.77 & 4.50 & 0.27 \\
9 & 5.10 & 4.91 & 0.18 \\
10 & 5.33 & 5.05 & 0.29 \\
11 & 5.45 & 5.00 & 0.45 \\
12 & 5.63 & 5.15 & 0.48 \\
Average & 4.52 & 4.28 & 0.24 \\
\hline
\end{tabular}

not have advantages in rating timeliness over Moody's in the post-Dodd-Frank period.

We further test our hypotheses by examining whether the rating differences between Moody's and EJR's ratings are associated with the information content of the creditworthiness of an issuer. The first hypothesis argues that EJR strategically underrates issuers in the low rating grades. If this argument is valid, we would expect that issuers who receive lower EJR's ratings than Moody's ratings may not have higher default risks. In the second hypothesis, we argue that Moody's is less (more) likely to downgrade (upgrade) issuers with downside (upside) threshold ratings than EJR. According to the argument of conflict of interest in issuer-paid CRAs, if an issuer receives a threshold rating from Moody's (e.g., A3) but a lower rating from EJR (e.g., $\mathrm{BBB}+$ ), then the issuer should have a higher default risk than implied by Moody's rating as it is supposed to be downgraded if not for the presence of a conflict of interest.

In line with prior studies (Poon and Shen 2020; Xia 2014), we measure the default risk of an issuer via expected default frequency (EDF), as obtained from Merton's model. The EDF is the probability that an issuer will default in the next 12 months, estimated from the option pricing model that takes equity value as a call option on the firm's total assets. First, we calculate the monthly EDF for 750 U.S. issuers in the sample. Thereafter, we test whether issuers with a lower rating by EJR (Hypothesis 1) or issuers with threshold ratings by Moody's (Hypothesis 2) are associated with higher default risk using ordinary least squares regression models. The results are presented in Table 6.

The key independent variables in columns (1) and (2) are binary dummy variables indicating whether EJR assigns a lower rating than Moody's in the speculative rating grades (LOWEREJR) and in the rating grades equal to or below Caa1/CCC + . Statistically insignificant results suggest that on average, issuers with lower ratings from EJR than from Moody's do not have higher default risks than the issuers rated the same by Moody's 
and EJR. The findings further confirm our first hypothesis that EJR strategically assigns overly harsh ratings to issuers with low rating grades, even though the creditworthiness of these issuers is not as poor as implied by the lower EJR's ratings.

The key independent variable (THRESHOLD) in column (3) is a binary dummy equal to one if an issuer receives a threshold rating (Aa3, A3, Baa3, Ba3, B3) from Moody's but a lower rating from EJR. Likewise, the main independent term (Baa3) in column (4) is a binary dummy variable that is equal to one if an issuer receives a Baa3 rating from Moody's but a lower rating from EJR. Statistically insignificant results indicate that on average, issuers with threshold ratings from Moody's, while with worse ratings from EJR, are not riskier. This means that we can reject Hypothesis 2 that asserts that issuer-paid CRAs are reluctant to downgrade issuers with downside threshold ratings even though these issuers deserve to be downgraded given their creditworthiness (EDF).

\section{Conclusion}

Many issuers (e.g., Lehman Brothers) rated by the major issuer-paid CRAs (Moody's and S\&P) enjoyed inflated investment-grade ratings shortly before defaulting. It is believed that the business model adopted by the issuer-paid CRAs creates a conflict of interest with issuers, which consequently leads to biased ratings (White 2019). The investor-paid rating business model is a suggested alternative to the issuer-paid model as the investorpaid CRAs are free from the conflict of interest with issuers (e.g., Kashyap and Kovrijnykh 2016). However, corresponding to SEC's concerns (see SEC 2012), some recent studies (e.g., Tang et al. 2020) have shown that investor-paid CRAs also have a conflict of interest inherent in their business model. We further argue that investor-paid CRAs may suffer from conflict of interest with themselves and greater information disadvantage such that they strategically underrate low-rating issuers to avoid missed defaults.

In the present study, we investigate the conflicts of interest in both business models in the credit rating industry. We collect the monthly data on issuer credit ratings of 750 U.S. firms assigned by EJR, a representative investor-paid CRA, and Moody's, one of the Big Three issuer-paid CRAs, between 2011 and 2018, that is, the post-Dodd-Frank period. We are the first to use the DDA to estimate the probability distribution of credit ratings in the full spectrum of rating grades and the downgrade and upgrade probabilities of credit ratings. Next, we compare the probabilities of rating changes over the full spectrum of rating grades between Moody's and EJR. We find that EJR is more likely to downgrade potentially defaulting issuers than Moody's probably because the former strategically assigns overly harsh ratings to these issuers. Moreover, there is no consistent and solid evidence to support the hypothesis that Moody's is positively biased toward issuers in the threshold ratings.

Overall, the findings of the present study show that although issuer-paid CRAs may suffer from a conflict of interest with the issuers, their ratings do not significantly favor issuers in comparison with investor-paid CRAs. We conjecture that if the financial markets discover an issuer-paid CRA's favoritism to one or more issuers, the issuer-paid CRA will lose its reputation in the accuracy of its future ratings. This 
Table 6 Rating difference between Moody's and EJR and default risk

\begin{tabular}{|c|c|c|c|c|}
\hline & (1) & (2) & (3) & (4) \\
\hline LOWEREJR & $\begin{array}{l}0.00 \\
(0.27)\end{array}$ & & & \\
\hline LOWEREJRCCC & & $\begin{array}{l}-0.01 \\
(-0.21)\end{array}$ & & \\
\hline THRESHOLD & & & $\begin{array}{l}0.01 \\
(0.48)\end{array}$ & \\
\hline Baa3 & & & & $\begin{array}{l}-0.00 \\
(-0.17)\end{array}$ \\
\hline SIZE & $\begin{array}{l}-0.05 \\
(-2.43)^{* *}\end{array}$ & $\begin{array}{l}-0.05 \\
(-2.44)^{* *}\end{array}$ & $\begin{array}{l}-0.05 \\
(-2.44)^{* *}\end{array}$ & $\begin{array}{l}-0.05 \\
(-2.45)^{* *}\end{array}$ \\
\hline LEV & $\begin{array}{l}0.16 \\
(2.52)^{* *}\end{array}$ & $\begin{array}{l}0.16 \\
(2.52)^{* *}\end{array}$ & $\begin{array}{l}0.16 \\
(2.54)^{* *}\end{array}$ & $\begin{array}{l}0.16 \\
(2.53)^{* *}\end{array}$ \\
\hline PROFIT & $\begin{array}{l}-1.12 \\
(-5.08)^{* * *}\end{array}$ & $\begin{array}{l}-1.13 \\
(-5.07)^{* * *}\end{array}$ & $\begin{array}{l}-1.12 \\
(-5.07)^{* * *}\end{array}$ & $\begin{array}{l}-1.12 \\
(-5.06)^{* * *}\end{array}$ \\
\hline LEVVOL & $\begin{array}{l}0.23 \\
(1.41)\end{array}$ & $\begin{array}{l}0.23 \\
(1.41)\end{array}$ & $\begin{array}{l}0.23 \\
(1.41)\end{array}$ & $\begin{array}{l}0.23 \\
(1.41)\end{array}$ \\
\hline RETSD & $\begin{array}{l}3.23 \\
(3.78)^{* * *}\end{array}$ & $\begin{array}{l}3.23 \\
(3.78)^{* * *}\end{array}$ & $\begin{array}{l}3.22 \\
(3.76)^{* * *}\end{array}$ & $\begin{array}{l}3.23 \\
(3.78)^{* * *}\end{array}$ \\
\hline Constant & $\begin{array}{l}0.41 \\
(2.09)^{* *}\end{array}$ & $\begin{array}{l}0.41 \\
(2.09)^{* *}\end{array}$ & $\begin{array}{l}0.40 \\
(2.09)^{* *}\end{array}$ & $\begin{array}{l}0.41 \\
(2.09)^{* *}\end{array}$ \\
\hline Moody's rating dummy & Yes & Yes & Yes & Yes \\
\hline Year dummy & Yes & Yes & Yes & Yes \\
\hline Number of observations & 36,388 & 36,388 & 36,388 & 36,388 \\
\hline R-squared & 0.695 & 0.695 & 0.695 & 0.695 \\
\hline
\end{tabular}

The dependent variable is the expected default frequency (EDF) of an issuer in a month. The control variables include firm total assets (SIZE), leverage ratio (LEV), operating profitability (PROFIT), the volatility of leverage ratio (LEVVOL) and the standard deviation of stock return (RETSD). These variables have consistent signs, magnitudes and statistical significance of coefficients. The dummies of Moody's ratings in each rating grade and year dummies are also included in the regression models. $t$-statistics are in parentheses

${ }^{*},{ }^{* *}$, and ${ }^{* * *}$ Correspond to statistical significance at the $10 \%, 5 \%$, and $1 \%$ levels, respectively

consequently implies that future issuers will less likely hire such a CRA (e.g., Bolton, et al. 2012). Accordingly, as the expected long-run gains from maintaining a reputation in the industry exceed the short-run gains of pleasing one or more issuers, the issuerpaid CRA endeavors to provide unbiased credit assessment to issuers. Furthermore, the Dodd-Frank Act, by imposing effective regulatory discipline, particularly on NRSROs, may constitute another factor that enforces rating accuracy and timeliness. Additionally, investor-paid CRAs appear to have inherent conflicts of interest, including the bias toward investors and themselves. Thus, the investor-paid business model may not be a valid alternative to resolve the ongoing problems in the credit rating industry. 


\section{Appendix}

See Table 7.

Table 7 Conversion scale from numerical to relative credit ratings by Moody's and EJR

\begin{tabular}{lllll}
\hline $\begin{array}{l}\text { Moody's credit } \\
\text { ratings }\end{array}$ & EJR's credit ratings & $\begin{array}{l}\text { Numerical credit } \\
\text { ratings }\end{array}$ & $\begin{array}{l}\text { Relative credit } \\
\text { ratings }\end{array}$ & \\
\hline Aaa & AAA & 22 & 1.6245 & Investment grade \\
Aa1 & AA+ & 21 & 1.5506 & \\
Aa2 & AA & 20 & 1.4768 & \\
Aa3 & AA- & 19 & 1.4029 & \\
A1 & A+ & 18 & 1.3291 \\
A2 & A & 17 & 1.2553 & \\
A3 & A- & 16 & 1.1814 & Speculative grade \\
Baa1 & BBB+ & 15 & 1.1076 \\
Baa2 & BBB & 14 & 1.0337 & \\
Baa3 & BBB- & 13 & 0.9599 & \\
Ba1 & BB+ & 12 & 0.8861 & \\
Ba2 & BB & 11 & 0.8122 \\
Ba3 & BB- & 10 & 0.7384 \\
B1 & B & 9 & 0.6645 & \\
B2 & B & 8 & 0.5907 & \\
B3 & B- & 7 & 0.5169 \\
Caa1 & CCC+ & 6 & 0.4430 \\
Caa2 & CCC & 5 & 0.3692 \\
Caa3 & CCC- & 4 & 0.2954 \\
Ca & CC & 3 & 0.2215 \\
C & C & 2 & 0.1477 & \\
& D & 1 & 0.0738 & \\
\hline
\end{tabular}

\section{Abbreviations}

CRA: Credit rating agency; DDA: Distribution dynamics approach; EDF: Expected default frequency; EJR: Egan-Jones Ratings Company; RCR: Relative credit ratings; S\&P: Standard \& Poor's Global Ratings; NRSRO: Nationally recognized statistical rating organization; OCR: The Office of Credit Ratings; SEC:The U.S. Securities and Exchange Commission.

\section{Acknowledgements}

The authors appreciate the editor, Professor Kou Kang and four referees for their constructive comments. The authors would like to thank K.Y Fan and Chun Kit Cheung for the dependable research assistants.

\section{Authors' contributions}

JS prepared dataset for analysis. JS and TSC participated in the design of the study and performed the statistical analysis. WCL and MW helped to draft the manuscript. All authors read and approved the final manuscript.

\section{Funding}

This research was funded by Research Grants Council, Hong Kong, Grant Number UGC/FDS14/B20/16 and the Hong Kong Polytechnic University, Grant Number P0030199.

\section{Availability of data and materials}

The data that support the findings of this study are available from Bloomberg and Moody's but restrictions apply to the availability of these data, which were used under license for the current study, and so are not publicly available. Data are however available from the authors upon reasonable request and with permission of Bloomberg and Moody's.

\section{Declarations}

\section{Competing interests}

The authors declare that they have no competing interests. 


\section{Author details}

${ }^{1}$ Department of Economics and Finance, The Hang Seng University of Hong Kong, Siu Lek Yuen, Hong Kong, China.

2ZN721, Block Z, Department of Building and Real Estate, The Hong Kong Polytechnic University, Hung Hom, Hong Kong, China.

Received: 18 February 2021 Accepted: 8 June 2021

Published online: 16 June 2021

\section{References}

Atilgan Y, Ghosh A, Yan M, Zhang J (2015) Cross-listed bonds, information asymmetry, and conservatism in credit ratings. J Money Credit Bank 47(5):897-929. https://doi.org/10.1111/jmcb.12232

Baghai RP, Becker B (2018) Non-rating revenue and conflicts of interest. J Financ Econ 127(1):94-112. https://doi.org/10. 1016/j.jineco.2017.10.004

Beaver WH, Shakespeare C, Soliman MT (2006) Differential properties in the ratings of certified versus non-certified bondrating agencies. J Account Econ 42(3):303-334. https://doi.org/10.1016/j.jacceco.2006.06.002

Berwart E, Guidolin M, Milidonis A (2019) An empirical analysis of changes in the relative timeliness of issuer-paid vs. investor-paid ratings. J Corp Financ 59:88-118. https://doi.org/10.1016/j.jcorpfin.2016.10.011

Bhattacharya U, Wei KD, Xia H (2019) Follow the money: investor trading around investor-paid credit rating changes. J Corp Financ 58:68-91. https://doi.org/10.1016/j.jcorpfin.2019.04.008

Bolton P, Freixas X, Shapiro J (2012) The credit ratings game. J Financ 67(1):85-111. https://doi.org/10.1111/j.1540-6261. 2011.01708.x

Bonsall SB (2014) The impact of issuer-pay on corporate bond rating properties: evidence from Moody's and S\&P's initial adoptions. J Account Econ 57(2-3):89-109. https://doi.org/10.1016/j.jacceco.2014.01.001

Bonsall SB, Koharki K, Neamtiu M (2017) When do differences in credit rating methodologies matter? Evidence from high information uncertainty borrowers. Account Rev 92(4):53-79. https://doi.org/10.2308/accr-51641

Calomiris C (2009) A recipe for ratings reform. Econ Voice 6(11):1-4. https://doi.org/10.2202/1553-3832.1678

Cheong TS, Wu Y (2018) Convergence and transitional dynamics of China's industrial output: A county-level study using a new framework of distribution dynamics analysis. China Econ Rev 48:125-138. https://doi.org/10.1016/j.chieco. 2015.11.012

Cheong TS, Wu Y, Wu J (2016) Evolution of carbon dioxide emissions in Chinese cities: trends and transitional dynamics. Asia Pac J Manag 21(3):357-377. https://doi.org/10.1080/13547860.2016.1176642

Egan Jones Ratings Co. (EJR) (2008) Application for registration as a Nationally Recognized Statistical Rating Organization

Cornaggia J, Cornaggia KJ (2013) Estimating the costs of issuer-paid credit ratings. Rev Financ Stud 26(9):2229-2269. https://doi.org/10.1093/rfs/hht041

Covitz DM, Harrison P (2003) Testing conflicts of interest at bond rating agencies with market anticipation: evidence that reputation incentives dominate. Board of Governors of the Federal Reserve System. Finance and Economics Discussion Series (FEDS). https://www.federalreserve.gov/pubs/feds/2003/200368/200368pap.pdf. Accessed 23 Jan 2019

deHaan E (2017) The financial crisis and corporate credit ratings. Account Rev 92(4):161-189. https://doi.org/10.2308/ accr-51659

Dichev ID, Piotroski JD (2001) The long-run stock returns following bond ratings changes. J Financ 56(1):173-203. https:// doi.org/10.1111/0022-1082.00322

Dimitrov V, Palia D, Tang L (2015) Impact of the Dodd-Frank act on credit ratings. J Financ Econ 115(3):505-520. https:// doi.org/10.1016/j.jfineco.2014.10.012

Efing M, Hau H (2015) Structured debt ratings: evidence on conflicts of interest. J Financ Econ 116(1):46-60. https://doi. org/10.1016/j.jfineco.2014.11.009

Frydman H, Schuermann T (2008) Credit rating dynamics and Markov mixture models. J Bank Financ 32(6):1062-1075. https://doi.org/10.1016/j.jbankfin.2007.09.013

Fulghieri P, Strobl G, Xia H (2014) The economics of solicited and unsolicited credit ratings. Rev Financ Stud 27(2):484518. https://doi.org/10.1093/rfs/hht072

He JJ, Qian JQ, Strahan PE (2012) Are all ratings created equal? The impact of issuer size on the pricing of mortgagebacked securities. J Financ 67(6):2097-2137. https://doi.org/10.1111/j.1540-6261.2012.01782.x

Jiang JX, Stanford MH, Xie Y (2012) Does it matter who pays for bond rating? Hist Evid J Financ Econ 105(3):607-621. https://doi.org/10.1016/j.jineco.2012.04.001

Johnson AP (2005) A continuous state space approach to "'convergence by parts."'Econ Lett 86(3):317-321

Kashyap AK, Kovrijnykh N (2016) Who should pay for credit ratings and how? Rev Financ Stud 29(2):420-456. https://doi. org/10.1093/rfs/hhv127

Kedia S, Rajgopal S, Zhou XA (2017) Large shareholders and credit ratings. J Financ Econ 124(3):632-653. https://doi.org/ 10.1016/j.jineco.2017.03.007

Kisgen DJ (2006) Credit ratings and capital structure. J Financ 61(3):1035-1072. https://doi.org/10.1111/j.1540-6261.2006. 00866.x

Kliger D, Sarig O (2000) The information value of bond ratings. J Financ 55(6):2879-2902. https://doi.org/10.1111/00221082.00311

Kou G, Xu Y, Peng Y, Shen F, Chen Y, Chang K, Kou S (2021) Bankruptcy prediction for SMEs using transactional data and two-stage multiobjective feature selection. Decis Supp Syst. https://doi.org/10.1016/j.dss.2020.113429

Kraft P (2015) Do rating agencies cater? Evidence from rating-based contracts. J Account Econ 59(2-3):264-283. https:// doi.org/10.1016/j.jacceco.2014.09.008

Li S, Cheong TS (2016) Convergence and mobility of rural household income in China: New evidence from a transitional dynamics approach. China Agric Econ Rev 8(3):383-398. https://doi.org/10.1108/CAER-09-2015-0126 
Parnes D (2018) Observed leniency among the credit rating agencies. J Fix Income 28(1):48-60. https://doi.org/10.3905/ jfi.2018.28.1.048

Parnes D, Akron S (2016) Rating the credit rating agencies. Appl Econ 48(50):4799-4812. https://doi.org/10.1080/00036 846.2016 .1164826

Pittman M (2008) Moody's, S\&P defer cuts on AAA subprime, hiding loss. Bloomberg News Service, 11 Mar 2008. https:// www.bloomberg.com/news/articles/2008-03-11/-1-200-aaa-1-i5s9y0mw. Accessed 23 Jan 2019

Poon WPH (2003) Are unsolicited credit ratings biased downward? J Bank Financ 27(4):593-614. https://doi.org/10.1016/ S0378-4266(01)00253-9

Poon WPH, Shen J (2020) The roles of rating outlooks: the predictor of creditworthiness and the monitor of recovery efforts. Rev Quant Financ Account 55:1063-1091. https://doi.org/10.1007/s11156-019-00868-7

Poon WPH, Lee J, Gup BE (2009) Do solicitations matter in bank credit ratings? Results from a study of 72 countries. J Money Credit Bank 41(2-3):285-314. https://doi.org/10.1111/j.1538-4616.2009.00206.x

Poon WPH, Shen J, Burnett JE (2017) An empirical study of international spillover of sovereign risk to bank credit risk. Financ Rev 52(2):281-302. https://doi.org/10.1111/fire.12114

Quah D (1993) Empirical cross-section dynamics in economic growth. Eur Econ Rev 37(2-3):426-434. https://doi.org/10. 1016/0014-2921(93)90031-5

Scannell K (2013) Egan-Jones is given SEC ratings ban. Financial Times, 23 Jan 2013. Available online. https://www.ft.com/ content/492473fe-64be-11e2-ac53-00144feab49a. Accessed 14 Apr 2021.

SEC (2003) Report on the role and function of credit rating agencies in the operation of securities markets. https://www. sec.gov/news/studies/credratingreport0103.pdf. Accessed 23 Jan 2019

SEC (2012) Report to Congress on assigned credit ratings. https://www.sec.gov/news/studies/2012/assigned-credit-ratin gs-study.pdf. Accessed 15 Dec 2020

SEC (2015) SEC announces charges against Standard \& Poor's for fraudulent ratings misconduct. https://www.sec.gov/ news/pressrelease/2015-10.html. Accessed 15 Apr 2021

SEC (2020a) Current NRSROs. https://www.sec.gov/ocr/ocr-current-nrsros.html. Accessed 15 Apr 2021

SEC (2020b) Egan Jones comments on file number 265-30, comments to the Committee meeting to be held on February 10, 2020. https://www.sec.gov/comments/265-30/26530-6732296-207477.pdf. Accessed 15 Dec 2020

SEC (2020c) Annual report on Nationally Recognized Statistical Rating Organizations. January 2020. https://www.sec.gov/ files/2019-annual-report-on-nrsros.pdf. Accessed 13 Apr 2021

SEC (2020d) Annual report on Nationally Recognized Statistical Rating Organizations. December 2020. https://www.sec. gov/files/2020-annual-report-on-nrsros.pdf. Accessed 13 Apr 2021

SEC (2021) About the office of credit ratings. https://www.sec.gov/ocr/Article/ocr-about.html. Accessed 13 Apr 2021

Shen F, Zhao X, Kou G (2020) Three-stage reject inference learning framework for credit scoring using unsupervised transfer learning and three-way decision theory. Decis Supp System. https://doi.org/10.1016/j.dss.2020.113366

Shen J, Shum WY, Cheong TS, Wang L (2021) COVID-19 and regional income inequality in China. Public Health Front 9:687152. https://doi.org/10.3389/fpubh.2021.687152

Silverman BW (1986) Density estimation for statistics and data analysis. Chapman and Hall, New York

Tang L, Peytcheva M, Li P (2020) Investor-paid ratings and conflicts of interest. J Bus Ethic 163:365-378. https://doi.org/10. 1007/s10551-018-4042-8

Toscano F (2020) Does the Dodd-Frank Act reduce the conflict of interests of credit rating agencies? J Corp Financ https://doi.org/10.1016/j.jcorpfin.2020.101595

Wang H, Kou G, Peng Y (2020) Multi-class misclassification cost matrix for credit ratings in peer-to-peer lending. J Oper Res Soc 72(4):923-934. https://doi.org/10.1080/01605682.2019.1705193

White LJ (2019) The credit rating agencies and their role in the financial system. In: Brousseau E, Glachant J-M, Sgard J (Eds) The Oxford handbook of institutions of international economic governance and market regulation. Oxford University Press. https://doi.org/10.1093/oxfordhb/9780190900571.013.38

Wu J-X, He L-Y (2017) How do Chinese cities grow? A distribution dynamics approach. Phys A Stat Mech Appl 470:105118. https://doi.org/10.1016/j.physa.2016.11.112

Wu J, Wu Y, Guo X, Cheong TS (2016) Convergence of carbon dioxide emissions in Chinese cities: a continuous dynamic distribution approach. Energ Polic 91:207-219. https://doi.org/10.1016/j.enpol.2015.12.028

Xia H (2014) Can investor-paid credit rating agencies improve the information quality of issuer-paid rating agencies? J Financ Econ 111(2):450-468. https://doi.org/10.1016/j.jineco.2013.10.015

Xia H, Strobl G (2012) The issuer-pays rating model and ratings inflation: Evidence from corporate credit ratings. https:// doi.org/10.2139/ssrn.2002186. Accessed 1 Aug 2020

Xing H, Sun N, Chen Y (2012) Credit rating dynamics in the presence of unknown structural breaks. J Bank Financ 36(1):78-89. https://doi.org/10.1016/j.jbankfin.2011.06.005

Xing H, Wang K, Li Z, Chen Y (2020) Statistical surveillance of structural breaks in credit rating dynamics. Entropy. https:// doi.org/10.3390/e22101072

\section{Publisher's Note}

Springer Nature remains neutral with regard to jurisdictional claims in published maps and institutional affiliations. 